Journal of Didactic Mathematics

2021, 2(1), 33-41

Doi: $10.34007 /$ jdm.v2i1.616

(1) https://mahesainstitute.web.id/ojs2/index.php/jdm

journalofdidacticmathematics@gmail.com

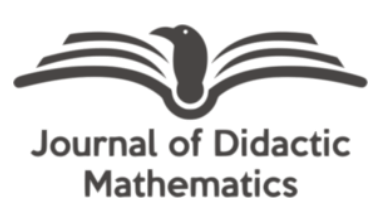

\title{
Peningkatan kemampuan pemecahan masalah matematis siswa melalui penerapan model pembelajaran missouri mathematic project
}

\author{
Boni Harianda \\ STKIP Insan Madani Airmolek, Kabupaten Indragiri Hulu, Indonesia, 29352
}

\section{Beni Junedi*}

Universitas Bina Bangsa, Kota Serang Banten, Indonesia, 42124

*Corresponding Author: beni.junedi@binabangsa.ac.id

\begin{abstract}
Problem solving is a basic skill that should be possessed by students. Mathematical problem-solving abilities play a role in solving every problem both other subjects and problems in everyday life. Through mathematical problemsolving activities students are directed to build mathematical knowledge, think logically, systematically and measurably. The fact is that students' mathematical problem-solving abilities are still low. The learning process that focuses on exercises that provide opportunities for students to develop mathematical problemsolving skills to become a model for improvement in the learning process. The Missouri Mathematical Project learning model is an appropriate learning model to facilitate students in developing their thinking in solving mathematical problemsolving problems. For this reason, this study aims to improve students' mathematical problem-solving abilities through the application of the Missouri mathematical learning model. This type of research is a classroom action research (PTK). The research subjects were grade V students of MIS Al Firdausy Pematang Reba. The data collection technique used was a mathematical problem-solving ability test. The data analysis technique used is quantitative data analysis. Based on the results of the test of mathematical problem-solving abilities, there was an increase in each cycle starting from the initial pre-action test, cycle I and cycle II. It can be concluded that there is an increase in students' mathematical problemsolving abilities through the application of the Missouri mathematical learning model.
\end{abstract}

Historis Artikel:

Diterima: 13 Maret 2021

Direvisi: 17 Maret 2021

Disetujui: 22 April 2021

\section{Keywords:}

mathematical problem-

solving; missouri

mathematic project;

project assignments

Sitasi: Harianda, B., \& Junedi, B. (2021). Peningkatan kemampuan pemecahan masalah matematis siswa melalui penerapan model pembelajaran missouri mathematic project. Journal of Didactic Mathematics, 2(1), 33-41. Doi: $10.34007 / j \mathrm{dm} . v 2 \mathrm{i} 1.616$

\section{PENDAHULUAN}

Pemecahan masalah merupakan suatu kemampuan yang seharusnya dimiliki siswa setelah belajar matematika. Kemampuan ini diperlukan siswa untuk memecahkan masalah yang dihadapinya dalam kehidupan sehari-hari karena kemampuan pemecahan masalah matematis dapat membantu siswa dalam memecahkan persoalan baik dalam pelajaran lain maupun dalam kehidupan sehari-hari. Melalui pemecahan masalah siswa diarahkan dalam membangun pengetahuan matematika, memecahkan masalah dalam berbagai konteks, menerapkan strategi pemecahan masalah, dan merefleksikan proses pemecahan masalah matematika (Anggo, 2011). Pentingnya kemampuan pemecahan masalah dinyatakan dalam National Council of Teachers of Mathematics (NCTM) bahwa pemecahan masalah harus menjadi fokus pada pembelajaran matematika pada setiap level sekolah. Guru memiliki peranan penting dalam menumbuhkembangkan kemampuan pemecahan masalah matematis pada setiap siswa baik pada proses dan penilaian pembelajaran berupa pemberian soal-soal pemecahan masalah (Sumartini, 
2016). Dalam meningkatkan kemampuan pemecahan masalah perlu pengembangan dalam bentuk keterampilan memahami masalah, membuat model matematika, menyelesaikan masalah dan menafsirkan solusi yang diperoleh (Hidayat \& Sariningsih, 2018).

Beberapa permasalahan pembelajaran matematika di sekolah berdasarkan hasil observasi pertama, siswa belum bisa membuat perencanaan menyelesaikan soal karena siswa bergantung pada contoh soal yang diberikan oleh guru. Kemampuan pemecahan masalah tidak terbatas fokus kepada menyelesaikan suatu permasalahan dengan cara yang disampaikan guru, akan tetapi lebih mengelaborasikan kemampuan siswa (Aisyah et al., 2018). Kedua, siswa kurang mampu menafsirkan dan membuat model matematika dari soal berbentuk pemecahan masalah. Kurangnya ketertarikan siswa pada pembelajaran matematika dapat dilihat ketika siswa mengalami kesulitan dalam soal pemecahan masalah. Pemecahan masalah perlu pengetahuan, kemampuan, sesiapan, kreativitas, dan penerapan nyata dalam membantu menyelesaikan berbagai persoalan (Yuhani et al., 2018). Ketiga, siswa terbukti mencantumkan hasil akhir tanpa mengerjakan langkah-langkah penyelesaian dikarenakan belum memahami pengertian soal-soal yang berkaitan dengan pemecahan masalah. Siswa terkadang malas memecahkan masalah disebabkan kurangnya pengetahuan yang dimiliki untuk menyelesaikan permasalahan tersebut (Putra et al., 2018).

Hasil pengamatanpada proses pembelajaran di MIS Al Firdausy Pematang Reba menunjukan siswa mengalami kesulitan dalam menyelesaikan soal-soal matematika yang berupa soal pemecahan masalah matematis. Rendahnya kemampuan pemecahan masalah matematis siswadalam pembelajaran. Siswa kesulitan dalam memahami soal pemecahan masalah dalam bentuk soal cerita. Beberapa penelitian terdahulu juga mengalami permasalah yang sama seperti; siswa belum mampu memahami maksud dari soal cerita serta kesalahan prosedur dalam menguraikan dan mengerjakan soal (Yuwono et al., 2018). Siswa fokus pada rumus tercepat untuk menyelesaikan soal yang bersifat konsep, bukan yang bersifat soal pemecahan masalah. Banyak siswa yang menjawab soal tanpa menuliskan unsur-unsur yang diketahui, ditanyakan, dan unsur yang perlu dilengkapi (Nufus et al., 2019).Gambaran permasalahan di atas menunjukan bahwa pembelajaran matematika perlu diperbaiki guna meningkatkan kemampuan dalam menyelesaikan soal cerita. Kemampuan pemecahan masalah matematis masih rendah, perlu peninjauan kembali perencanaan pembelajaran matematika yang dapat meningkatkan kemampuan pemecahan masalah siswa secara makasimal (Ulya, 2015). Memecahkan masalah merupakan kemampuan yang sulit dipelajari oleh siswa (Rinaldi \& Afriansyah, 2019). Apabila siswa telah terlatih dalam menyelesaikan masalah, siswa akan mampu mengambil keputusan terhadap solusi dari suatu permasalahan berdasarkan keterampilan mengumpulkan informasi, menganalisis informasi dan menelaah kembali hasil yang diperoleh (Junedi \& Juliana, 2019).

Penggunaan model pembelajaran missouri mathematics project (MMP) memfasilitasi siswa untuk memahami berbagai soal pemecahan masalah yang diselesaikan secara individual dan kelompok. Langkah-langkah MMP terdiri dari peninjaun kembali materi sebelumnya, pengembangan, bekerja berkelompok, belajar mandiri dan penugasan (Handayani et al., 2018). Model ini memberikan kesempatan pada siswa untuk belajar berkelompok dalam latihan terkontrol dan mengaplikasikan belajar mandiri dalam seatwork. (Fauziah \& Sukasno, 2015). Pada model ini siswa diberikan tugas proyek yang berisikan rangkain soal dan perintah yang mengembangkan ide dan konsep matematika yang dikerjakan secara kelompok dan individu sehingga siswa diberikan kesempatan untuk mengaplikasikan pemahamannya (Purwanti, 2015). Model pembelajaran MMP memberikan kesempatan keleluasaan berpikir kepada siswa secara berkelompok dalam menyelesaikan permasalahan yang diberikan oleh guru berkaitan dengan materi pelajaran (Rahmiati \& Fahrurrozi, 2016). Model pembelajaran missouri mathematics project merupakan model pembelajaran yang dirancang untuk meningkatkan kemampuan siswa dalam memecahkan masalah matematika sehingga pada akhirnya siswa mampu menyusun jawaban mereka sendiri karena banyaknya pengalaman yang dimiliki siswa dalam menyelesaikan soal-soal latihan. 


\section{METODE}

Jenis penelitian merupakan penelitian tindakan kelas yang dilaksanakan di kelas V MIS Al Firdausy Pematang Reba. Desain penelitian tindakan ini menggunakan model Kemmis dan Mc Taggart terdapat empat tahapan dalam setiap siklus, yaitu perencanaan, pelaksanaan, pengamatan, dan refleksi (Mashuri et al., 2019). Apabila pada tindakan sudah mencapai tujuan yang diharapkan 70\% siswa mengalami ketuntasan secara klasikal, maka langsung ditarik kesimpulan, tetapi jika belum memenuhi ketuntasan klasikal maka dilanjutkan pada siklus berikutnya. Penelitian tindakan kelas ini bertujuan untuk meningkatkan kemampuan pemecahan masalah matematis siswa kelas V MIS Al Firdausy. Subjek penelitian merupakan siswa kelas V MIS Al Firdausy Pematang Reba yang berjumlah 30 siswa dengan objeknya model pembelajaran missouri mathematics project. Teknik pengumpulan data yang digunakan berupa tes kemampuan pemecahan masalah matematis siswa yang dibuat di setiap siklusnya terdiri dari 5 butir soal essay. Teknik analisis data menggunakan analisis data kuantitatif.

\section{HASIL DAN PEMBAHASAN}

Hasil penelitian terdiri dari hasil pra tindakan dan hasil tindakan.

\section{Pra tindakan}

Kegiatan pra tindakan dilakukan sebagai acuan untuk dilaksanakan kegiatan pada siklus I untuk mengetahui kemampuan pemecahan masalah matematis siswa. Hasil tes awal menunjukan rendahnya kemampuan pemecahan masalah matematis siswa. Hasil tes disajikan pada tabel berikut.

Tabel 1. Hasil Tes Awal Kemampuan Pemecahan Masalah Matematis

\begin{tabular}{|c|c|c|c|c|c|}
\hline \multirow[b]{2}{*}{ Indikator } & \multicolumn{4}{|c|}{ Persentase } & \multirow[b]{2}{*}{ Rata-rata } \\
\hline & Soal 1 & Soal 2 & Soal 3 & Soal 4 & \\
\hline $\begin{array}{l}\text { Kemampuan siswa mengidentifikasi data } \\
\text { diketahui dan ditayakan, kecukupan data untuk } \\
\text { pemecahan. }\end{array}$ & 67 & 57 & 60 & 56 & $58 \%$ \\
\hline $\begin{array}{l}\text { Kemampuan siswa mengidentifikasi strategi yang } \\
\text { dapat ditempuh. }\end{array}$ & 53 & 50 & 50 & 44 & $49 \%$ \\
\hline $\begin{array}{l}\text { Kemampuan siswa menyelesaikan model } \\
\text { matematika disertai alasan }\end{array}$ & 43 & 43 & 40 & 34 & $34 \%$ \\
\hline $\begin{array}{l}\text { Kemampuan siswa memeriksa kebenaran solusi } \\
\text { yang diperoleh }\end{array}$ & 14 & 10 & 17 & 14 & $14 \%$ \\
\hline Rata-rata & 44,25 & 40 & 32,75 & 37 & $38,75 \%$ \\
\hline
\end{tabular}

Berdasarkan tabel di atas rata-rata kemampuan pemecahan masalah matematis siswa masih rendah karena persentase ketuntasan masih di bawah $70 \%$, sehingga mendorong untuk melakukan pelaksanaan tindakan. Pada tahap pra tindakan diperoleh temuan-temuan beberapa aspek yang perlu diperbaiki dalam pembelajaran, yaitu:

a. Pentingnya memotivasi siswa dalam proses pembelajaran

b. Pentingnya meningkatkan kemampuan pemecahan masalah matematis siswa

c. Memfasilitasi siswa dengan menyediakan lembar kerja siswa, peralatan lain yang menunjang siswa dalam kegiatan belajar matematika.

\section{Hasil Tindakan}

1. Deskripsi Siklus I

Setelah kegiatan pratindakan dianalisis dan direfleksi maka dilanjutkan dengan siklus I. Siklus ini terdiri dari 4 tahap

\section{Perencanaan Siklus I}

Pada tahap ini menyusun perencanaan pembelajaran matematika sebagai berikut: (a) Mempersiapkan alat dan media yang akan digunakan dalam model pembelajaran missouri 
mathematic project, (b) Mempersiapkan perangkat pembelajaran dan rencana pelaksanaan pembelajaran (RPP); dan (c) Menyiapkan lembar kerja siswa (LKS).

\section{Pelaksanaan Siklus I}

Pada tahap pelaksanaan menggunakan model missouri mathematic project dengan berpedoman pada rencana pelakasanaan pembelajaran (RPP) Kurikulum 2013 dengan indikator mengumpulkan dan membandingkan data dengan pencatatan langsung serta menyebutkan data dalam bentuk tabel dan diagram. Tindakan yang dilakukan mengikuti langkah-langkah model pembelajaran missouri mathematic project. Proses yang dilakukan pada siklus I yaitu: (a) Guru memberikan materi secara singkat dengan mengaitkan materi pembelajaran pengolahan data dikelas 4; (b) Guru memberikan kesempatan kepada siswa untuk bertanya dan membagi siswa menjadi 6 kelompok; (c) Guru memberikan lembar kerja siswa secara berkelompok dan tiap-tiap kelompok mempresentasikan hasil kegiatannya didepan kelas; (d) Guru memberikan penilaian terhadap tugas yang sudah dilaksanakan; dan (e) Menyimpulkan materi pembelajaran.

\section{Pengamatan}

Pada tahap ini kegiatan yang dilakukan berupa pengamatan terhadap situasi kegiatan pembelajaran, keterlibatan siswa pada kegiatan pembelajaran, kemampuan siswa dalam bekerja sama dalam kelompok, kemampuan siswa dalam mempresentasikan hasil diskusi dan kemampuan siswa dalam menjawab soal secara individu, perubahan-perubahan yang terjadi atau lancar tidaknya penggunaan model yang digunakan.Setelah pelaksanaan kegiatan dilakukan tes kemampuan pemecahan masalah matematis siswa pada siklus I dapat dilihat pada tabel berikut.

Tabe1 2. Hasil Tes Kemampuan Pemecahan Masalah Matematis Siswa Siklus I

\begin{tabular}{lccccc}
\hline \multicolumn{1}{c}{ Indikator } & \multicolumn{3}{c}{ Persentase } & \multicolumn{2}{c}{ Rata-rata } \\
\cline { 2 - 5 } & Soal 1 & Soal 2 & Soal 3 & Soal 4 & \\
\hline $\begin{array}{l}\text { Kemampuan siswa mengidentifikasi data diketahui dan } \\
\text { ditayakan, kecukupan data untuk pemecahan. }\end{array}$ & 80 & 77 & 66 & 73 & $72 \%$ \\
$\begin{array}{l}\text { Kemampuan siswa mengidentifikasi strategi yang dapat } \\
\text { ditempuh. }\end{array}$ & 70 & 66 & 60 & 63 & $65 \%$ \\
$\begin{array}{l}\text { Kemampuan siswa menyelesaikan model matematika } \\
\text { disertai alasan }\end{array}$ & 66 & 60 & 53 & 57 & $59 \%$ \\
$\begin{array}{l}\text { Kemampuan siswa memeriksa kebenaran solusi yang } \\
\text { diperoleh }\end{array}$ & 50 & 47 & 44 & 50 & $48 \%$ \\
\hline \begin{tabular}{l} 
Rata-rata \\
\hline
\end{tabular} & 66,5 & 62,5 & 55,8 & 60,8 & $61 \%$ \\
\hline
\end{tabular}

Berdasarkan hasil tes pra tindakan dan tes siklus I diperoleh data sebagai berikut.

Tabel 3. Perbandingan Hasil Tes Kemampuan Pemecahan Masalah

\begin{tabular}{lcc}
\multicolumn{1}{c}{ Indikator } & Tes awal & Siklus 1 \\
\hline Kemampuan siswa mengidentifikasi data diketahui dan ditayakan, kecukupan data & $58 \%$ & $72 \%$ \\
untuk pemecahan. & & \\
Kemampuan siswa mengidentifikasi strategi yang dapat ditempuh. & $49 \%$ & $65 \%$ \\
Kemampuan siswa menyelesaikan model matematika disertai alasan & $34 \%$ & $59 \%$ \\
Kemampuan siswa memeriksa kebenaran solusi yang diperoleh & $14 \%$ & $48 \%$ \\
\hline Rata-rata & $38,75 \%$ & $61 \%$ \\
\hline
\end{tabular}

Kemampuan pemecahan masalah matematis siswa meningkat berdasarkan perbandingan tes awal dan tes yang dilaksanakan di siklus I. Namun hasil tindakan siklus I masih dikategorikan belum berhasil dan perlu dilakukan peningkatan kembali.

\section{Refleksi Siklus I}

Setelah proses pembelajaran berlansung guru melakukan refleksi, terlihat hasil yang diperoleh siswa belum memenuhi kriteria ketuntasan belajar yang telah ditentukan. Ada beberapa 
Peningkatan kemampuan pemecahan masalah matematis siswa...

yang harus diperbaiki yaitu (1) Perlunya memperhatikan alokasi waktu yang dibutuhkan sesuai yang direncanakan didalam rencana pelaksanaan pembelajaran (RPP); dan (2) Perlunya memotivasi siswa untuk bekerja sama ketika diberikan tugas secara berkelompok dan memotiva sisiswa agar tidak takut bertanya.

\section{Deskripsi Siklus II}

\section{Perencanaan Siklus II}

Adapun pada siklus II adalah memperbaiki pada pelaksanaan pembelajaran yang lebih fokus pada siswa yang masih dibawah nilai ketuntasan minimal (KKM). Dalam kegiatan perencanaan Siklus II ini yang dilakukan adalah: (a) Membuat RPP dengan menggunakan prosedur pembelajaran missouri mathematic project, (b) Menyusun soal-soal kedalam LKS untuk dikerjakan dalam kelompok dan individu; (c) Merancang teknik pengelolaan kelas, pengaturan tempat duduk, setting kelas dan menentukan kelompok siswa; dan (d) Menyiapkan alat pengumpul data berupates kemampuan pemecahan masalah matematis siswa.

\section{Proses pelaksanaan Siklus II}

Pada pelaksanaan siklus II dilaksanakan dalam 2 kali pertemuan dengan menerapkan model missouri mathematic project untuk meningkatkan kemampuan pemecahan masalah matematis. Pelaksanaan siklus II terdiri dari (a) Melaksanakan model pembelajaran missouri mathematic project dengan membagi siswa berkelompok; (b) Guru meninjau kembali materi sebelumnya dan mengaitkan materi hari ini secara singkat menjelang pembagian tugas kelompok; (c) Guru memberikan LKS yang akan dikerjakan siswa secara berkelompok dan individu Selanjutnya guru memberikan penilaian terhadap tugas yang sudah dilaksanakan; dan (d) Meyimpulkan materi pembelajaran.

\section{Pengamatan}

Pada tahap pengamatan dilakukan tes kemampuan pemecahan masalah matematis siswa. Hasil pengamatan disajikan pada tabel berikut.

Tabel 4. Hasil Tes Kemampuan Pemecahan Masalah Matematis Siswa Siklus II

\begin{tabular}{lccccc}
\multicolumn{1}{c}{ Indikator } & \multicolumn{4}{c}{ Persentase } & Rata-Rata \\
\cline { 2 - 5 } & Soal 1 & Soal 2 & Soal 3 & Soal 4 & Rat \\
\hline $\begin{array}{l}\text { Kemampuan siswa mengidentifikasi data diketahui dan } \\
\text { ditayakan, kecukupan data untuk pemecahan. }\end{array}$ & 90 & 87 & 83 & 87 & $87 \%$ \\
$\begin{array}{l}\text { Kemampuan siswa mengidentifikasi strategi yang dapat } \\
\text { ditempuh. }\end{array}$ & 83 & 80 & 73 & 77 & $78 \%$ \\
$\begin{array}{l}\text { Kemampuan siswa menyelesaikan model matematika } \\
\text { disertai alasan }\end{array}$ & 77 & 80 & 63 & 67 & $72 \%$ \\
$\begin{array}{l}\text { Kemampuan siswa memeriksa kebenaran solusi yang } \\
\text { diperoleh }\end{array}$ & 67 & 56 & 56 & 53 & $58 \%$ \\
\hline Rata-rata & 79,3 & 75,8 & 68,8 & 71 & $73,8 \%$ \\
\hline
\end{tabular}

Berdasarkan hasil tes siklus I dan II diperoleh data perbandingan sebagai berikut.

Tabel 5. Perbandingan Hasil Tes Kemampuan Pemecahan Masalah Matematis

\begin{tabular}{lcc}
\multicolumn{1}{c}{ Indikator } & Siklus I & Siklus II \\
\hline Kemampuan siswa mengidentifikasi data diketahui dan ditayakan, kecukupan data & $72 \%$ & $87 \%$ \\
untuk pemecahan. & & \\
Kemampuan siswa mengidentifikasi strategi yang dapat ditempuh. & $65 \%$ & $78 \%$ \\
Kemampuan siswa menyelesaikan model matematika disertai alasan & $59 \%$ & $72 \%$ \\
Kemampuan siswa memeriksa kebenaran solusi yang diperoleh & $48 \%$ & $58 \%$ \\
\hline Rata-rata & $61 \%$ & $73,8 \%$ \\
\hline
\end{tabular}



berikut.

Berdasarkan hasil tes pra tindakan, siklus I dan II diperoleh data perbandingan sebagai

Tabel 6. Perbandingan Hasil Tes Kemampuan Pemecahan Masalah Matematis

\begin{tabular}{lccc}
\multicolumn{1}{c}{ Indikator } & Tes Awal & Siklus I & Siklus II \\
\hline $\begin{array}{l}\text { Kemampuan siswa mengidentifikasi data diketahui dan ditayakan, } \\
\text { kecukupan data untuk pemecahan. }\end{array}$ & $58 \%$ & $72 \%$ & $87 \%$ \\
Kemampuan siswa mengidentifikasi strategi yang dapat ditempuh. & $49 \%$ & $65 \%$ & $78 \%$ \\
Kemampuan siswa menyelesaikan model matematika disertai alasan & $34 \%$ & $59 \%$ & $72 \%$ \\
Kemampuan siswa memeriksa kebenaran solusi yang diperoleh & $14 \%$ & $48 \%$ & $58 \%$ \\
\hline Rata-rata & $38,75 \%$ & $61 \%$ & $73,8 \%$ \\
\hline
\end{tabular}

Berdasarkan pelaksanaan siklus II dengan perbandingan hasil dari siklus I sesuai dengan rencana pelaksanaan pembelajaran (RPP) Kurikulum 2013 telah mencapai peningkatan signifikan artinya penggunaan model missouri mathematic project dalam pembelajaran ini berhasil dengan ketuntasan klasikal lebih dari $70 \%$.

Refleksi

Pada akhir siklus IImelakukan refleksi dengan adanya penerapan model pembelajaran missouri mathematic project terlihat peningkatan kemampuan pemecahan masalah matematis siswa danmemutuskan untuk berhenti di siklus II. Peningkatan kemampuan pemecahan masalah matematis siswa dipengaruhi oleh model pembelajaran missouri mathematic project. Hal ini terlihat dari indikator-indikator kemampuan pemecahan masalah matematis siswa sebagai berikut.

\section{Kemampuan mengidentifikasi data diketabui dan ditanyakan, kecukupan data untuk pemecahan}

Pada indikator ini nilai tes yang diperoleh oleh siswa mengalami peningkatan dibandingkan sebelum dilaksanakan tindakan kelas. Berdasarkan tes awal yang diberikan banyak siwa yang langsung menuliskan rumus dan melanjutkan mengerjakan masalah matematika. Selain itu ada beberapa siswa yang mencantumkan hasil akhirnya saja tanpa mengidentifikasi apa yang diketahui dan apa yang ditanya dalam soal. Siswa mengalami kesalahan dalam mengidentfikasi data yang diketahui, Hal ini dikarenakan siswa mengalami kesulitan memahami soal pemecahan masalah yang diberikan.Hal ini menyebabkan siswa salah mengerjakan penyelesaian matematika. Oleh karena itu perlu menambahkan lebih banyak latihan soal yang berupa soal cerita agar siswa berlatih menganalisa permasalahan matematika. Sehingga siswa dapat merumuskan masalah dengan tepat.Pada tindakan siklus II, peneliti memberikan perbaikan pada proses mengidentifikasi data diketahui dan ditanyakan,kecukupan data untuk pemecahan berupa latihan dalam menganalisa soal cerita lebih banyak. Sehingga mampu mengurangi permasalahan pada siklus I.

\section{Kemampuan mengidentifikeasi strategi yang dapat ditempuh}

Pada kondisi awal sebelum diberikan siswa kurang mampu mengidentifikasi strategi yang dapat ditempuh. Pada tahap ini siswa menentukan rumus yang akan digunakan dan langkahlangkah untuk mengerjakan masalah matematika. Banyak siswa yang belum mampu mengidentifikasi strategi yang dapat ditempuh dalam menyelesaikan soal pemecahan masalah yang diberikan. Hal ini disebabkan karena siswa sulit memahami rumus yang harus digunakan. Pada siklus II, diadakan perbaikan dalam mengidentifikasi strategi yang dapat ditempuh dengan memberikan latihan soal yang menggunakan rumus bervariasi sehingga siswa mudah memahami dan membedakan rumus yang digunakan.

\section{Kemampuan melaksanakan rencana penyelesaian}

Pada indikator ini siswa menyelesaikan masalah matematika sesuai dengan yang telah direncanakan sebelumnya. Apabila pada lndikator sebelumnya mengalami kesalahan maka hasil 
penyelesaian juga salah. Sebelum diberikan tindakan banyak siswa mengalami kesulitan mengerjakan soal disebabkan kurangnya pemahaman pada soal dan langkah-langkah yang tidak sesuai. Sehingga dilakukan perbaikan dengan melaksanakan tindakkan siklus I dengan hasil meningkat namun belum mencapai kriteria yang telah ditentukan. Untuk memperbaiki kekurangan tersebut, diberikan latihan soal-soal yang memuat dengan operasi hitung matematika agar siswa lebih hati-hati dan teliti dalam menghitung. Pada tindakan siklus II, terjadi peningkatan terhadap indicator.

\section{Kemampuan memeriksa kebenaran solusi yang diperoleh}

Pada indikator ini kesalahanbanyak terjadi pada siswa, hampir seluruh siswa tidak membuktikan kebenaran soal atau tidak memeriksa kembali apakah hasil yang dikerjakan benar atau salah. Berbagai alasan dapat ditemukan seperti malas membaca kembali, waktu yang tidak cukup bahkan menyerahdengan jawaban yang dikerjakan. Tindakan yang dilakukan memberikan arahan kepada siswa pentingnya memeriksa kembali hasil yang telah dikerjakan sehingga terjadi peningkatan hasil tes kemampuan pemecahan masalah matematis baik siklus I maupun siklus II.

Berdasarkan penelitian yang telah dilakukan pada kelas V MIS Al Firdausy, menyimpulkan bahwa terjadi peningkatan kemampuan pemecahan masalah matematis siswamelaui model pembelajaran missouri mathematic project. Hal ini disebabkan karena dalam proses pembelajaran guru memberikan lembar kerja siswa yang berisikan tugas proyek. Siswa mengerjakan tugas dengan cara berkelompok dan dilanjutkan dengan tugas secara individual. Penerapan model pembelajaran missouri mathematic project dapat membantu siswa dalam meningkatkan kemampuan pemecahan masalah matematis siswa, karena siswa saling berdiskusi, berkomunikasi dalam kelompok untuk memecahkan permasalahan yang diberikan oleh guru. Disamping itu siswa yang berkemampuan tinggi dapat membantu siswa yang berkemampuan rendah.Dalam proses pelaksanaanya guru memberikan soal latihan terkontrol dalam bentuk tugas proyek sehingga apabila siswa mengalami kendala atau permasalahan guru secara cepat merespon permasalahan tersebut.

Tugas proyek yang diberikan kepada siswa membantu siswa dalam meningkatkan kemampuan pemecahan masalah matematisnya. Tugas proyek ini diberikan pada langkah latihan terkontrol dan tugas mandiri. Latihan terkontrol merupakan langkah kegiatan yang di kontrol oleh guru dalam mengerjakan tugas proyek yang diberikan sehingga siswa terlatih dalam mengerjakan soal-soal pemecahan masalah. Dengan adanya tugas proyek ini siswa menjadi lebih kreatif dalam mengintegrasikan pengetahuannya sehingga lebih melatih kemampuan pemecahan masalah matematisnya. Disamping itu siswa diberikan kebebasan untuk menyelesaikan berbagai macam alternatif penyelesaian permasalahan yang ditemukan sendiri sehingga memberikan kesempatan kepada siswa untuk membangun pengetahuannya sendiri. Tugas proyek ini dikerjakan secara berkelompok dan individu. Dengan adanya kegiatan berkelompok memberikan kesempatan pada siswa untuk saling berbagi pengetahuan tentang alternatif penyelesaian permasalahan yang diberikan oleh guru. Sehingga terjadi interaksi positif antar siswa di dalam proses pembelajaran. Penerapan model ini mendorong siswa terlibat aktif di dalam proses pembelajaran dan bekerja sama antar kelompok (Satania \& Fitriyana, 2015).

Tugas proyek berupa latihan memberikan kesempatan kepada siswa untuk terampil dalam menyelesaikan soal-soal pemecahan masalah matematis. Keterampilan itu dibentuk pada saat belajar secara berkelompok dan secara individu atau mandiri. Dengan adanya kegiatan tugas proyek ini secara langsung membentuk kebiasaan siswa dalam menyelesaikan proyek tepat waktu, tepat sasaran karena adanya batas waktu pengerjaan yang diberikan. Pemberiaan alokasi waktu yang diatur membuat banyak materi yang dapat disampaikan dan banyak latihan yang dikerjakan siswa sehingga siswa terampil dalam mengerjakan tugas proyek (Rahmiati \& Fahrurrozi, 2016)

\section{KESIMPULAN}

Berdasarkan hasil penelitian tindakan kelas yang telah dilakukan di kelas V MIS Al 
Firdausy, dapat diambil kesimpulan bahwa terjadi peningkatan kemampuan pemecahan masalah matematis siswa melalui model pembelajaran missouri mathematic project. Peningkatan terjadi pada siklus I yang dibandingkan dengan tes awal, kemudian siklus II yang dibandingkan dengan siklus I dan tes awal. Penerapan model pembelajaran missouri mathematic project memberikan kesempatan pada siswa melatih keterampilan dalam meningkatkan kemampuan melalui tugas proyek yang dikerjakan sebagai latihan terkontrol secara berkelompok dan tugas secara mandiri. Dengan adanya berbagai latihan yang diberikan sehingga siswa mampu menyelesaikan berbagai macam soal-soal pemecahan masalah matematis. Penerapan missouri mathematic project perlu perencanaan yang tepat agar kegiatan kelompok dan individual berjalan dengan baik dan sesuai dengan tujuan pembelajaran. Penerapan missouri mathematic project perlu inovasi lagi baik bagi guru maupun peneliti selanjutnya. Inovasi berupa pengaturan belajar kelompok maupun individual yang dilengkapai dengan rancangan tugas yang lebih kompleks.

\section{DAFTAR PUSTAKA}

Aisyah, P. N., Nurani, N., Akbar, P., \& Yuliani, A. (2018). Analisis Hubungan Kemampuan Pemecahan Masalah Matematis dan Self Confidence Siswa SMP. Jurnal on Education, 1(1), 58-65. https://doi.org/10.22460/jpmi.v1i5.p881-886

Anggo, M. (2011). Pelibatan Metakognisi Dalam Pemecahan Masalah Matematika. Edumatica, 01(April), 25-32.

Fauziah, A., \& Sukasno, S. (2015). Pengaruh Model Missouri Mathematics Project (Mmp) Terhadap Kemampuan Pemahaman Dan Pemecahan Masalah Matematika Siswa Sma N I Lubuklinggau. Infinity Journal, 4(1), 10. https://doi.org/10.22460/infinity.v4i1.67

Handayani, I., Januar, R. L., \& Purwanto, S. E. (2018). The effect of Missouri mathematics project learning model on students' mathematical problem solving ability. Journal of Physics: Conference Series, 948(1). https://doi.org/10.1088/1742-6596/948/1/012046

Hidayat, W., \& Sariningsih, R. (2018). Kemampuan Pemecahan Masalah Matematis dan Adversity Quotient Siswa SMP melalui Pembelajaran Open Ended. Jurnal JNPM Jurnal Nasional Pendidikan Matematika), 2(1). https://doi.org/10.1016/S0962-8479(96)90008-8

Junedi, B., \& Juliana, J. (2019). Penerapan Strategi Pembelajaran Interaktif Dengan Teknik Pembelajaran Kolaboratif Send-a-Problem Terhadap Kemampuan Pemecahan Masalah Matematis Siswa Kelas Ix Smp. MES: Journal of Mathematics Education and Science, 4(2), 139_ 144. https://doi.org/10.30743/mes.v4i2.1289

Mashuri, S., Djidu, H., \& Ningrum, R. K. (2019). Problem-based learning dalam pembelajaran matematika: Upaya guru untuk meningkatkan minat dan prestasi belajar siswa. Pythagoras: Jurnal Pendidikan Matematika, 14(2), 112-125. https://doi.org/10.21831/pg.v14i2.25034

Nufus, H., Wira, C., \& Kurniati, A. (2019). Pengaruh Penerapan Model Learning Cycle 7E terhadap Kemampuan Pemecahan Masalah Matematis ditinjau berdasarkan Kemampuan Kemandirian Belajar Siswa SMPN 31 Pekanbaru. Juring (Journal of Research in Mathematics Learning), 2(3), 199-210.

Purwanti, S. (2015). Meningkatkan Kemampuan Komunikasi dan Berpikir Kritis Matematis Siswa Sekolah Dasar Dengan Model Missouri Mathematics Project (MMP). TERAMPIL Jurnal Pendidikan Dan Pembelajaran Dasar, 2(2), 253-266.

Putra, H. D., Thahiram, N. F., Ganiati, M., \& Nuryana, D. (2018). Kemampuan Pemecahan Masalah Matematis Siswa SMP pada Materi Bangun Ruang. JIPM Jurnal Ilmiah Pendidikan Matematika), 6(2), 82-90.

Rahmiati, R., \& Fahrurrozi, F. (2016). Pengaruh Pembelajaran Missouri Mathematics Project (Mmp) Terhadap Kemampuan Pemecahan Masalah Matematika. Jurnal Pendidikan Matematika, 10(2), 1-12. https://doi.org/10.22342/jpm.10.2.3634.75-86

Rinaldi, E., \& Afriansyah, E. A. (2019). Perbandingan Kemampuan Pemecahan Masalah Matematis Siswa antara Problem Centered Learning dan Problem Based Learning. NUMERICAL: Jurnal Matematika Dan Pendidikan Matematika, 3(1), 9-18. 
Peningkatan kemampuan pemecahan masalah matematis siswa...

https://doi.org/10.25217/numerical.v3i1.326

Satania, R. U., \& Fitriyana, N. (2015). Implementasi Model Missouri Mathematics Project Dengan Metode Inquiry Pada Kemampuan Pemecahan Masalah Matematika. Epsilon, 2, 2015. http://weekly.cnbnews.com/news/article.html?no=124000

Sumartini, T. S. (2016). Peningkatan Kemampuan Pemecahan Masalah Matematis Siswa melalui Pembelajaran Berbasis Masalah. Jurnal Pendidikan Matematika "Mosharafa,"5(2).

Ulya, H. (2015). Hubungan Gaya Kognitif dengan Kemampuan Pemecahan Masalah Matematika Siswa. Jurnal Konseling GUSJIGANG, 1(2).

Yuhani, A., Zanthy, L. S., \& Hendriana, H. (2018). Pengaruh Pembelajaran Berbasis Masalah Terhadap Kemampuan Pemecahan Masalah Matematis Siswa Smp. JPMI Jurnal Pembelajaran Matematika Inovatif), 1(3), 445. https://doi.org/10.22460/jpmi.v1i3.p445-452

Yuwono, T., Supanggih, M., \& Ferdiani, R. D. (2018). Analisis Kemampuan Pemecahan Masalah Matematika dalam Menyelesaikan Soal Cerita Berdasarkan Prosedur Polya. Jurnal Tadris Matematika, 1(2), 137-144. https://doi.org/10.21274/jtm.2018.1.2.137-144 